\title{
Role of entities of human resource management in personnel controlling
}

\author{
Izabela Stańczyk \\ Jagiellonian University \\ Aneta Kuźniarska \\ Jagiellonian University
}

\section{Introduction}

At present in the organizations in question, one of the elements of effective and efficient management of human resources is the skill of utilizing information from the indicators of personnel controlling. Controlling is increasingly becoming the tool for implementation that is made available to employees at various levels of management. These employees, who are divided up into entities of the management of human resources, generate the appropriate behaviour in terms of the execution of the assumed goals of the organization.

The aim of the herein paper is to present the role that is played by the particular entities of the management of human resources in terms of the execution of the assumptions of personnel controlling. The research questions were formulated as follows: "What are the most important aims of operational personnel controlling according to the entities of human resource management?", "What are the most important aims of strategic personnel controlling according to the entities of human resource management?". 


\section{Entities of human resource management}

The execution of the strategic aims in an organization requires the cooperation of all the people that create it by constituting the entities of human resource management (HRM). In accordance with Król ${ }^{1}$ and Pocztowski ${ }^{2}$, these are, among others, top management, line managers, personnel managers and employees. Oleksyn additionally enumerates the owners, as well as the personnel unit or department ${ }^{3}$. The framework division of roles of these entities is presented in Table 1.

Table 1. Framework division of roles of entities in the sphere of human resource management - chosen elements

\begin{tabular}{|c|c|c|c|c|}
\hline Area-function & Top management & Other managers & $\begin{array}{l}\text { Personnel } \\
\text { specialists }\end{array}$ & Employees \\
\hline $\begin{array}{l}\text { Selection of top } \\
\text { management }\end{array}$ & $\begin{array}{l}\text { Propositions } \\
\text { relating to vice- } \\
\text { chairmen and } \\
\text { members of the } \\
\text { board }\end{array}$ & - & Formal service & - \\
\hline $\begin{array}{l}\text { Shaping } \\
\text { strategies } \\
\text { and policies } \\
\text { of human } \\
\text { resource } \\
\text { management }\end{array}$ & $\begin{array}{l}\text { Decisions, } \\
\text { supervision } \\
\text { of execution }\end{array}$ & $\begin{array}{l}\text { Propositions } \\
\text { relating } \\
\text { to entrusted } \\
\text { areas, } \\
\text { suggestions } \\
\text { of changes } \\
\text { in strategies } \\
\text { for the whole } \\
\text { organization }\end{array}$ & \begin{tabular}{|l|} 
Projects, \\
propositions, \\
coordination, \\
functional \\
supervision
\end{tabular} & $\begin{array}{l}\text { Participation } \\
\text { in designing } \\
\text { strategies } \\
\text { of human } \\
\text { resource } \\
\text { management } \\
\text { at expert level }\end{array}$ \\
\hline $\begin{array}{l}\text { Division of labour } \\
\text { and shaping } \\
\text { organizational } \\
\text { structures }\end{array}$ & $\begin{array}{l}\text { Decisions } \\
\text { on scale } \\
\text { of organization }\end{array}$ & $\begin{array}{l}\text { Decisions } \\
\text { on scale of area }\end{array}$ & \begin{tabular}{|l|} 
Projects, \\
coordination
\end{tabular} & Propositions \\
\hline $\begin{array}{l}\text { Definition } \\
\text { of content } \\
\text { of organizational } \\
\text { roles }\end{array}$ & $\begin{array}{l}\text { Acknowledge- } \\
\text { ment of princi- } \\
\text { ples }\end{array}$ & $\begin{array}{l}\text { Substantive } \\
\text { decisions }\end{array}$ & $\begin{array}{l}\text { Advice in sphere } \\
\text { of methodics }\end{array}$ & $\begin{array}{l}\text { Active } \\
\text { participation } \\
\text { in optimization } \\
\text { and technical } \\
\text { work }\end{array}$ \\
\hline
\end{tabular}

1 H. Król, Istota rozwoju kapitału ludzkiego w organizacji, [in:] H. Król, A. Ludwiczyński (eds), Zarzq̨dzanie zasobami ludzkimi. Tworzenie kapitału ludzkiego organizacji, Wydawnictwo Naukowe PWN, Warszawa 2006.

2 A. Pocztowski, Zarzqdzanie zasobami ludzkimi, Polskie Wydawnictwo Ekonomiczne, Warszawa 2018.

3 T. Oleksyn, Zarządzanie zasobami ludzkimi w organizacji, Wolters Kluwer, Warszawa 2017, pp. 67-71. 


\begin{tabular}{|c|c|c|c|c|}
\hline Area-function & Top management & Other managers & $\begin{array}{l}\text { Personnel } \\
\text { specialists }\end{array}$ & Employees \\
\hline $\begin{array}{l}\text { Definition } \\
\text { of working } \\
\text { standards }\end{array}$ & $\begin{array}{l}\text { Acceptance } \\
\text { of principles and } \\
\text { systems }\end{array}$ & $\begin{array}{l}\text { Leading } \\
\text { functions } \\
\text { in a particular } \\
\text { area }\end{array}$ & $\begin{array}{l}\text { Advice, } \\
\text { coordination }\end{array}$ & $\begin{array}{l}\text { Participation, } \\
\text { execution }\end{array}$ \\
\hline $\begin{array}{l}\text { Management } \\
\text { of competences }\end{array}$ & $\begin{array}{l}\text { Acknowledge- } \\
\text { ment of system } \\
\text { and associated } \\
\text { procedures }\end{array}$ & $\begin{array}{l}\text { In a designated } \\
\text { area }\end{array}$ & \begin{tabular}{|l|} 
General concept, \\
coordination, \\
substantive \\
supervision \\
\end{tabular} & $\begin{array}{l}\text { Propositions, } \\
\text { execution }\end{array}$ \\
\hline $\begin{array}{l}\text { Controlling } \\
\text { employment and } \\
\text { labour costs }\end{array}$ & $\begin{array}{l}\text { Guidelines and } \\
\text { approval }\end{array}$ & $\begin{array}{l}\text { Projects and } \\
\text { propositions }\end{array}$ & $\begin{array}{l}\text { Projects and } \\
\text { coordination }\end{array}$ & $\begin{array}{l}\text { Partial impact } \\
\text { on quality and } \\
\text { dimension } \\
\text { of employment } \\
\end{array}$ \\
\hline Outsourcing & $\begin{array}{l}\text { Acknowledge- } \\
\text { ment of princi- } \\
\text { ples and deci- } \\
\text { sions referring } \\
\text { to important } \\
\text { issues }\end{array}$ & $\begin{array}{l}\text { Decisions } \\
\text { of lower level } \\
\text { of importance }\end{array}$ & $\begin{array}{l}\text { Projects and } \\
\text { conducting } \\
\text { system on the } \\
\text { scale of the } \\
\text { firm, general } \\
\text { supervision } \\
\text { of functional } \\
\text { elements }\end{array}$ & $\begin{array}{l}\text { Propositions, } \\
\text { participation } \\
\text { in operationaliza- } \\
\text { tion }\end{array}$ \\
\hline $\begin{array}{l}\text { Recruitment and } \\
\text { selection of staff }\end{array}$ & $\begin{array}{l}\text { Staffing } \\
\text { important } \\
\text { positions }\end{array}$ & $\begin{array}{l}\text { Participation, } \\
\text { decisions relating } \\
\text { to recruitment } \\
\text { to organization }\end{array}$ & $\begin{array}{l}\text { System, } \\
\text { participation, } \\
\text { service }\end{array}$ & $\begin{array}{l}\text { Participation } \\
\text { in process } \\
\text { of internal } \\
\text { recruitment }\end{array}$ \\
\hline $\begin{array}{l}\text { Motivation and } \\
\text { remuneration }\end{array}$ & \begin{tabular}{|l} 
Direct \\
subordinates
\end{tabular} & Subordinates & $\begin{array}{l}\text { Designing, } \\
\text { advice, training, } \\
\text { inspection }\end{array}$ & $\begin{array}{l}\text { Self-motivation, } \\
\text { suggestions for } \\
\text { change }\end{array}$ \\
\hline $\begin{array}{l}\text { Professional } \\
\text { enhancement }\end{array}$ & $\begin{array}{l}\text { Acknowledge- } \\
\text { ment of system } \\
\text { and plans }\end{array}$ & $\begin{array}{l}\text { Planning, } \\
\text { execution, } \\
\text { inspection }\end{array}$ & $\begin{array}{l}\text { Advisory } \\
\text { service, training, } \\
\text { inspection }\end{array}$ & $\begin{array}{l}\text { Propositions, } \\
\text { self-participation }\end{array}$ \\
\hline $\begin{array}{l}\text { Records and } \\
\text { analysis }\end{array}$ & \begin{tabular}{|l|} 
Definition of self- \\
needs, general \\
supervision, \\
utilization in the \\
decision-making \\
process on the \\
scale of the firm
\end{tabular} & $\begin{array}{l}\text { Definition of self- } \\
\text { needs, general } \\
\text { supervision, } \\
\text { utilization in the } \\
\text { decision-making } \\
\text { process on the } \\
\text { scale of the } \\
\text { organizational } \\
\text { unit }\end{array}$ & \begin{tabular}{|l|} 
Advisory \\
functions, \\
leading and \\
coordination \\
functions on the \\
scale of the firm, \\
direct execution \\
in the sphere \\
of its parts \\
\end{tabular} & $\begin{array}{l}\text { Executive } \\
\text { functions, } \\
\text { propositions } \\
\text { for streamlining } \\
\text { formulation } \\
\text { of applications }\end{array}$ \\
\hline
\end{tabular}

Source: self-analysis with supplementation on the basis of T. Oleksyn, Zarzqdzanie zasobami ludzkimi w organizacji, Wolters Kluwer, Warszawa 2017, pp. 67-71.

The principal task of the top management of an organization, which according to Oleksyn is "concentrated on strategic management and has the greatest knowledge of the market environment of the company at its disposal - in terms of its 
clients, trading partners and competitors" 4 , which is to build the strategies of HRM on the basis of the strategies of the organization. Activities associated with the selection of people for key positions ${ }^{5}$ is becoming equally important, as well as taking strategic decisions based on data analysis, including information acquired within the framework of the indicators of personnel controlling at a strategic level. The managers at the highest level should display the ability of efficient management, while also have an impact onco-workers and behave in an ethical manner in contacts with them. They should be strategists and visionaries in terms of shaping the power of the organization on the market ${ }^{6}$. The roles attributed to the top management are those of a visionary, architect and promoter ${ }^{7}$.

The medium level of management is first and foremost the execution of the function of the coordinator and integrator of the processes of labour. As emphasized by Oleksyn, "empowering the medium level management staff with the right to decide on the level and structure of employment, forms of remuneration and levels of individual salaries, promotions, working is generally speaking beneficial" 8 . Undertaking such decisions by this entity of HRM is frequently executed on the basis of indicator data within the framework of personnel controlling at an operational level, while also the budget and labour costs relating to a specific organizational unit. The essence of a manager of medium level is first and foremost the professional preparation in the sphere of HRM, the efficiency of leadership, while also the ethics of behaviour towards employees and co-workers, with particular regard for the interpersonal competences 9 . The medium level managers are defined by the roles of a facilitator, inspirer and mentor ${ }^{10}$.

The value of HRM in a firm may be realized by personnel specialists with the aid of the following five elements: familiarity with external business conditions, serving internal and external stakeholders, shaping the activities of HR, creating the HR resources, while also ensuring professionalism ${ }^{11}$. For the execution of these activities, it is necessary to ensure the professional competences of the employees in the personnel departments, designate their appropriate roles, while also possibilities of development.

$4 \quad$ Ibidem, p. 73

5 Ibidem, pp. 67-71.

6 A. Szejniuk, Managerial ethics in human resource management, "Journal of Modern Science" 2016, vol. 1, no. 28, pp. 89-104.

7 A. Pocztowski, Zarzqdzanie..., p. 68.

8 T. Oleksyn, Zarządzanie zasobami ludzkimi..., p. 74.

9 A. Szejniuk, Managerial ethics..., pp. 89-104.

10 A. Pocztowski, Zarzqdzanie..., pp. 203-204.

11 D. Urlich, W. Brockbank, Tworzenie wartości przez HR, Oficyna Wolters Kluwer business, Kraków 2008. 
Personnel specialists should fulfil the following roles: advisory, coordinative, training, service, agent of change, auditor ${ }^{12}$; integrator, advisor/auditor ${ }^{13}$; strategic partner, expert in the field of administration, ombudsman, animator of change ${ }^{14}$.

The final entity of HRM relates to the employees in non-managerial positions. These are authors or co-authors of various elements of HRM, who apply the processes of HRM, manage their own competences and their own development by means of activity in trade unions, participate in socio-occupational associations, while also assessing and contesting the existing state of affairs in the organization ${ }^{15}$. The employees may be expected to have "the willingness to take on responsibility for their own behaviour and professional career, to perceive the need for flexibility and cooperate with the appropriate line managers and personnel managers"16. The level of commitment of employees is becoming increasingly important in the management of an organization. According to Borkowska, there is evidence of the necessity to change the traditional model of management of human resources towards the construction and development of a model of management based on the commitment of employees ${ }^{17}$.

\section{Strategic and operational controlling}

Controlling constitutes a sub-system of management in an organization that coordinates planning, inspection and provision of information, thus supporting the adaptation and harmonization of the entire system of management. All activities conducted within the framework of controlling are geared towards controlling the entire enterprise with regard to the designated aims, namely the achievement of the previously defined results ${ }^{18}$. The essence of controlling is that of planning based on aims that are jointly designated by the operational management and members of the board, whereby its efficiency is achieved thanks to the constant comparison of the designated aims with their execution ${ }^{19}$. This constitutes a modern concept of management of a firm, which renders the efficient reaction

12 T. Oleksyn, Zarzqdzanie zasobami ludzkimi..., p. 76.

13 A. Pocztowski, Zarzqdzanie..., p. 70.

14 D. Urlich, Liderzy zarzq̨dzania zasobami ludzkimi, Oficyna Ekonomiczna, Kraków 2001.

15 T. Oleksyn, Zarzqdzanie zasobami ludzkimi..., p. 78.

16 A. Pocztowski, Zarzq̨dzanie zasobami ludzkimi. Zarys problematyki i metod, Antykwa, Kraków 1998, p. 38.

17 S. Borkowska, Rola zaangażowania pracowników, "Zarządzanie Zasobami Ludzkimi” 2014, no. 2, p. 9.

18 P. Horvath, Controlling, Verlag Franz Vahlen, München 2006.

19 H. Vollmuth, Controlling. Planowanie, kontrola, kierowanie, Placet, Warszawa 2007. 
to changes occurring in the environment possible, as well as adjusting to the requirements of a client ${ }^{20}$. According to Internationaler Controller Verein, controlling is a managerial process whose task is to support the management (managers) in the pursuit of achieving goals. Its foundations are: planning, calculation, control, management ${ }^{21}$.

The most general and most frequently applied classification of controlling is its division into strategic controlling and operational controlling. This division is conducted from the view point of the nature of tasks, levels of management and time horizon. Distinguishing these two types of controlling is significant in an organization due to the aims and precision of the gauges and predictions (compare Table 2).

Table 2. Features of strategic and operational controlling

\begin{tabular}{|c|c|c|}
\hline Feature & Strategic controlling & Operational controlling \\
\hline Aims & $\begin{array}{l}\text { Securing long-term existence and } \\
\text { development of enterprise, growth } \\
\text { of value of the firm }\end{array}$ & $\begin{array}{l}\text { Profitability, yield, solvency and } \\
\text { economic results }\end{array}$ \\
\hline $\begin{array}{l}\text { Orientation } \\
\text { towards }\end{array}$ & $\begin{array}{l}\text { External circumstances and shaping } \\
\text { aims and potential resources on their } \\
\text { basis, matching activities to changes } \\
\text { in the environs }\end{array}$ & $\begin{array}{l}\text { Utilization of existing resources, } \\
\text { economization and regulation } \\
\text { of internal processes }\end{array}$ \\
\hline $\begin{array}{l}\text { Subject } \\
\text { of tasks }\end{array}$ & Development of enterprise & Effective use of resources \\
\hline $\begin{array}{l}\text { Dimensions } \\
\text { viewed }\end{array}$ & $\begin{array}{l}\text { Opportunities, threats, strong and } \\
\text { weak points }\end{array}$ & $\begin{array}{l}\text { Revenue/outlays, costs/efficiency/ } \\
\text { profitability }\end{array}$ \\
\hline Time horizon & $\begin{array}{l}\text { Long or very long period, } \\
\text { unrestricted, perspectives }\end{array}$ & $\begin{array}{c}\text { On average up to } 3 \text { years, most } \\
\text { frequently short-term - one year, } \\
\text { quarter }\end{array}$ \\
\hline $\begin{array}{l}\text { Level } \\
\text { of planning }\end{array}$ & Strategic & Tactical and operative, budgeting \\
\hline $\begin{array}{l}\text { Structuring } \\
\text { problems }\end{array}$ & $\begin{array}{l}\text { Low degree of structuring, more } \\
\text { qualitative than quantitative nature } \\
\text { of aims and tasks }\end{array}$ & $\begin{array}{l}\text { Aims and tasks expressed } \\
\text { in quantitative terms, great precision } \\
\text { of data }\end{array}$ \\
\hline Type of control & System of early warning & $\begin{array}{l}\text { Ongoing control of budgets and } \\
\text { chosen indicators }\end{array}$ \\
\hline $\begin{array}{l}\text { Specification } \\
\text { of activities }\end{array}$ & Innovative & Routine \\
\hline
\end{tabular}

20 J. Konsek-Ciechońska, Operational and strategic controlling tools in microenterprises - case study, "Management Systems in Production Engineering" 2017, vol. 25, issue 4, pp. 278-282, http://doi.org/10.1515/mspe-2017-0041

21 Co to jest controlling, https://www.icv-controlling.com/pl/o-controllingu/co-to-jest-controlling.html (accessed: 1.12.2019). 


\begin{tabular}{|l|l|l|}
\hline \multicolumn{1}{|c|}{ Feature } & \multicolumn{1}{|c|}{ Strategic controlling } & \multicolumn{1}{c|}{ Operational controlling } \\
\hline $\begin{array}{l}\text { Degree } \\
\text { of formalizing } \\
\text { activities }\end{array}$ & Less formalized & More formalized \\
\hline $\begin{array}{l}\text { Dimension } \\
\text { of information }\end{array}$ & Irrational values, qualitative & Rational values, quantitative \\
\hline
\end{tabular}

Source: self-analysis on the basis of the following: Z. Sekuta, Controlling personalny. Część 1. Istota i przedmiot controllingu personalnego, Oficyna Wydawnicza Ośrodka Postępu Organizacyjnego Sp. z o.o., Bydgoszcz 1999; H. Walica, Inwestycje i controlling w przedsiębiorstwie, serie "Prace Naukowe Wyższej Szkoły Biznesu w Dąbrowie Górniczej”, Wyższa Szkoła Biznesu, Dąbrowa Górnicza 2007.

The role of strategic controlling is the fulfilment of long-term intentions, which are mainly reflected in the economic and financial performance. Its functioning is of particular importance for large enterprises where there is a need for a multidimensional coordination of aims and activities in the particular units in terms of maintaining the maximum flexibility and correctness of decisions ${ }^{22}$. The significant task of strategic controlling is as follows:

- the creation of organizational, methodological and informational conditions for the preparation and verification of strategic plans, while also to adjust them to management at an operational level;

- to support management in the embodiment of long-term plans referring to the development of the enterprise;

- to provide assistance in taking decisions with the aid of a system of managerial information, analysis of the reality of the aforesaid goals within a longterm timeframe, coordination of the process of planning in this sphere ${ }^{23}$, analysis of the long-term tasks and aims, or supervision of the processes of control at a strategic level 24 .

Long-term tasks and current plans for the functioning of an organization are connected by way of operational management. Operational controlling, which exists within its framework has the following tasks:

- analyse solvency, efficiency, while also the current profitability of the enterprise and concentration on the financial performance;

- execution of short-term and current goals;

- regulation of the processes within the organization, thus focusing on the issues associated with current functioning.

22 T. Reichmann, Controlling mit Kennzahlen, Verlag Franz Vahlen, München 2006.

23 S. Marciniak, Controlling. Filozofia, projektowanie, Difin, Warszawa 2001.

24 A. Skowronek-Mielczarek, Z. Leszczyński, Controlling, analiza i monitoring w zarządzaniu przedsiębiorstwem, Difin, Warszawa 2007. 
Quantitative methods are utilized for the fulfilment of tasks within the framework of operational controlling, which serve the comparison of budgets with the actual execution, while also the analysis of deviations, preparation of reports and data for the managers taking the current decisions ${ }^{25}$.

\section{Strategic and operational personnel controlling}

Deyhle defined personnel controlling as the concept of personnel management whose fundamental aim is that of thriftiness, as well as the identification of the personnel plan of the firm, which consequently means moving towards the processes of decentralization, management by aims, as well as motivation and remuneration ${ }^{26}$. This is distinguished by specialized tasks such as the following: control and coordination of the flow of information in the sphere of human resources, preparation of decisions associated with personnel by means of the analysis of information transferred by people and about people, while also monitoring the implementation of decisions ${ }^{27}$. This constitutes a system that renders transparent activities within the framework of HRM possible, while also their economicalness, effectiveness and orientation towards the established goals ${ }^{28}$. The basis of the analysis in personnel controlling is constituted by the following which exist in the area of processes: planning employment, recruitment and selection of candidates, evaluation of employees, ways of motivating them, remuneration, labour efficiency, severance, activities in the field of health and safety, labour costs, or implementation of the notion of sustainable personnel in the organization $^{29}$. With regard to the levels of management and the time horizon, personnel controlling may be divided into the following areas ${ }^{30}$ :

- strategic - the strategic system of human resource management and HR resources, whose task is to analyse the role of HR activities in terms of achieving the long-term goals of the firm, while also the optimization of activities in this sphere and creating feedback channels for key employees, particularly at managerial levels;

25 Ibidem.

26 A. Deyhle, Personal-Controlling, "Controller Magazin" 1990, no. 2, pp. 51-57, https://www .haufe.de/download/controller-magazin-ausgabe-021990-controller-magazin-139022.pdf (accessed: 22.12.2019).

27 C. Schulte, Personal-Controlling mit Kennzahlen, Verlag Franz Vahlen, München 2011.

28 J. Goliszewski, Controlling - koncepcje, zastosowania, wdrożenie, Oficyna Wolters Kluwer business, Warszawa 2015.

29 A. Kuźniarska, Controlling personalny w sieciach handlu detalicznego, Wydawnictwo Uniwersytetu Jagiellońskiego, Kraków 2019.

30 P. Břečková, K. Havlíček, Leaders Management and Personnel Controlling in SMEs, "European Research Studies" 2013, vol. XVI, issue 4, pp. 3-14. 
- operational - which applies the short-term system of indicators for evaluating employees, as well as the system of HR indicators used in the evaluation of HR processes and efficiency of the department (compare Table 3).

Table 3. Strategic and operational tasks of personnel controlling

\begin{tabular}{|c|c|}
\hline ersonnel controlling & Operational personnel controlling \\
\hline $\begin{array}{l}\text { - Ensuring integration of personnel strategies } \\
\text { with strategy of enterprise } \\
\text { - Inclusion of aspects of human resource } \\
\text { management into strategies of the whole } \\
\text { enterprise } \\
\text { - Indicating the best possible strategies for } \\
\text { execution by the enterprise } \\
\text { - Conducting research on dependency } \\
\text { between strategies of the enterprises and } \\
\text { personnel strategy } \\
\text { - Creation of long-term plans in the sphere } \\
\text { of human resource management } \\
\text { - Implementation of personnel strategies } \\
\text { by means of specific action } \\
\text { - Monitoring execution of strategies } \\
\text { - Preparation and utilization of system } \\
\text { of early warning with the aim of reacting } \\
\text { to change with the appropriate timescale } \\
\text { in advance }\end{array}$ & $\begin{array}{l}\text { - Participation in planning human resources } \\
\text { - Researching the degree of matching } \\
\text { - In the case of the failure to match } \\
\text { - indicating ways of elimination and } \\
\text { associated costs } \\
\text { - Rationalization of labour costs } \\
\text { - Indicating factors evoking labour costs } \\
\text { - Control of the accuracy of systems of staff } \\
\text { - } \text { assessment applied (or their creation) } \\
\text { and efficiency of work } \\
\text { - Evaluation of the efficiency of employees } \\
\text { responsible for conducting personnel } \\
\text { policies in the organization } \\
\text { - Comprehensive analysis of activities } \\
\text { undertaken within the framework of the } \\
\text { broad perception of human resource } \\
\text { management }\end{array}$ \\
\hline
\end{tabular}

Source: self-analysis on the basis of the following: A. Pocztowski, J. Purgat-Popiela, Controlling personalny, [in:] M. Sierpińska (ed.), Controlling funkcyjny w przedsiębiorstwie, Oficyna Ekonomiczna, Kraków 2004; A. Sikorski, Controlling personalny, "Zarządzanie Zasobami Ludzkimi” 2001, no. 2, pp. 49-58.

The essence of the functioning of strategic personnel controlling in an organization is the definition of the quantity and quality of the contribution of the personnel function in the development of the enterprise ${ }^{31}$, inclusion of the personnel aspects into the strategies of the enterprise, while also reacting to change in the strategic aims with the appropriate time in advance ${ }^{32}$.

In the case of operational personnel controlling, the tasks are concentrated on the ongoing personnel management with the application of the appropriate information based on the specificity of tasks ${ }^{33}$.

31 M. Sierpińska, B. Niedbała, Controlling operacyjny w przedsiębiorstwie, Wydawnictwo Naukowe PWN, Warszawa 2008.

32 Z. Sekuta, Controlling personalny. Część 1. Istota i przedmiot controllingu personalnego, Oficyna Wydawnicza Ośrodka Postępu Organizacyjnego Sp. z o.o., Bydgoszcz 1999.

33 A. Pocztowski, J. Purgat-Popiela, Controlling... 


\section{Strategic and operational aims of personnel controlling as exemplified by trading chains - research results}

The subject matter of the research conducted was that of an evaluation of the strategic and operational aims of personnel controlling in retail trading chains. The research was conducted between 2016 and 2017 in a large chain of supermarkets which operates across Poland (I am unsure if this was one chain or many chains), whereby a sample of 204 employees were selected (compare Table 4). The principal criteria of selecting the sample was the type of position held (not lower than a department specialist). The research was conducted with the aid of a survey questionnaire that included closed questions, while the evaluation was conducted in accordance with the five-degree Likert scale.

Table 4. Division of respondents according to position held in the organization

\begin{tabular}{|l|c|c|}
\hline \multicolumn{1}{|c|}{ Type of position held } & $\begin{array}{c}\text { Number of respondents } \\
\text { according to position held }\end{array}$ & $\begin{array}{c}\text { Percentage of those } \\
\text { analysed (\%) }\end{array}$ \\
\hline Director & 5 & 3 \\
\hline Department head & 17 & 8 \\
\hline Specialist of HR department & 41 & 20 \\
\hline Specialist of controlling department & 8 & 4 \\
\hline Remaining specialists & 133 & 65 \\
\hline SUM & 204 & 100 \\
\hline
\end{tabular}

Source: self-analysis.

During the course of the research, respondents were asked for an assessment of the aims of personnel controlling at a strategic level. In Table 5, the percentage levels of assessment indicators for each of the entities of HRM have been presented separately; whereby evaluation was noted between 1 and 5 on the Likerta scale, in which " 1 " denoteslittle, while " 5 " denotes great significance of the particular feature. The intensity of these features grows together with the growth infigures - the greater the numerical value, the greater the significance of the particular feature.

The strategic aims of personnel controlling were most highly rated by the top management - directors and managers, as well as specialists of controlling. In accordance with the described roles of these entities within HRM, personnel controlling constitutes their subject of work, while also the basic source of information for taking decisions. It has the least significance for specialists in the remaining departments. 
Table 5. Strategic aims of personnel controlling in evaluation of research entities (\%)

\begin{tabular}{|c|c|c|c|c|c|c|c|}
\hline No. & Type of aim & $\begin{array}{l}\text { Entity of human resource } \\
\text { management }\end{array}$ & 1 & 2 & 3 & 4 & 5 \\
\hline \multirow[t]{5}{*}{1} & \multirow{5}{*}{$\begin{array}{l}\text { Ensuring long-term } \\
\text { functioning of enterprise }\end{array}$} & Director & 20 & 0 & 20 & 20 & 40 \\
\hline & & Manager & 0 & 0 & 12 & 35 & 53 \\
\hline & & $\mathrm{HR}$ & 0 & 2 & 5 & 25 & 68 \\
\hline & & Specialist of controlling & 0 & 0 & 0 & 12 & 88 \\
\hline & & Remaining specialists & 3 & 6 & 11 & 18 & 62 \\
\hline \multirow[t]{5}{*}{2} & \multirow{5}{*}{$\begin{array}{l}\text { Enhancement of efficiency } \\
\text { of activities of enterprise }\end{array}$} & Director & 20 & 20 & 0 & 20 & 40 \\
\hline & & Manager & 0 & 0 & 29 & 18 & 53 \\
\hline & & $\mathrm{HR}$ & 0 & 2 & 5 & 41 & 52 \\
\hline & & Specialist of controlling & 0 & 0 & 0 & 0 & 100 \\
\hline & & Remaining specialists & 1 & 7 & 9 & 27 & 56 \\
\hline \multirow[t]{5}{*}{3} & \multirow{5}{*}{$\begin{array}{l}\text { Rapid reaction to changes } \\
\text { occurring in environment }\end{array}$} & Director & 0 & 0 & 20 & 40 & 40 \\
\hline & & Manager & 0 & 0 & 29 & 53 & 18 \\
\hline & & HR & 2 & 7 & 32 & 24 & 34 \\
\hline & & Specialist of controlling & 0 & 0 & 12 & 50 & 38 \\
\hline & & Remaining specialists & 5 & 6 & 26 & 35 & 28 \\
\hline \multirow[t]{5}{*}{4} & \multirow{5}{*}{$\begin{array}{l}\text { Improvement of financial } \\
\text { performance }\end{array}$} & Director & 0 & 20 & 20 & 40 & 20 \\
\hline & & Manager & 0 & 0 & 6 & 65 & 29 \\
\hline & & $\mathrm{HR}$ & 0 & 0 & 2 & 27 & 71 \\
\hline & & Specialist of controlling & 0 & 0 & 0 & 50 & 50 \\
\hline & & Remaining specialists & 1 & 6 & 14 & 32 & 47 \\
\hline \multirow[t]{5}{*}{5} & \multirow{5}{*}{$\begin{array}{l}\text { Evaluation of significance } \\
\text { of human resources for } \\
\text { company }\end{array}$} & \begin{tabular}{|l|} 
Director \\
\end{tabular} & 0 & 0 & 40 & 20 & 40 \\
\hline & & \begin{tabular}{|l|} 
Manager \\
\end{tabular} & 0 & 0 & 35 & 35 & 30 \\
\hline & & $\mathrm{HR}$ & 0 & 2 & 10 & 51 & 37 \\
\hline & & Specialist of controlling & 0 & 13 & 0 & 62 & 25 \\
\hline & & Remaining specialists & 2 & 3 & 19 & 33 & 43 \\
\hline \multirow[t]{5}{*}{6} & \multirow[t]{5}{*}{ Reduction of labour costs } & \begin{tabular}{|l|} 
Director \\
\end{tabular} & 20 & 0 & 40 & 0 & 40 \\
\hline & & Manager & 6 & 6 & 12 & 35 & 41 \\
\hline & & $\mathrm{HR}$ & 0 & 2 & 27 & 39 & 32 \\
\hline & & Specialist of controlling & 0 & 0 & 0 & 75 & 25 \\
\hline & & Remaining specialists & 5 & 5 & 18 & 34 & 38 \\
\hline \multirow[t]{5}{*}{7} & \multirow{5}{*}{$\begin{array}{l}\text { Provision of useful } \\
\text { information for taking } \\
\text { decisions }\end{array}$} & \begin{tabular}{|l|} 
Director \\
\end{tabular} & 0 & 0 & 20 & 40 & 40 \\
\hline & & Manager & 0 & 18 & 17 & 47 & 18 \\
\hline & & HR & 0 & 7 & 41 & 32 & 20 \\
\hline & & Specialist of controlling & 0 & 0 & 25 & 38 & 37 \\
\hline & & Remaining specialists & 2 & 12 & 23 & 37 & 26 \\
\hline \multirow[t]{5}{*}{8} & \multirow{5}{*}{$\begin{array}{l}\text { Enhancement of processes } \\
\text { of planning }\end{array}$} & \begin{tabular}{|l|} 
Director \\
\end{tabular} & 0 & 0 & 40 & 20 & 40 \\
\hline & & Manager & 12 & 12 & 6 & 46 & 24 \\
\hline & & $\mathrm{HR}$ & 5 & 12 & 34 & 22 & 27 \\
\hline & & Specialist of controlling & 0 & 0 & 12 & 75 & 13 \\
\hline & & Remaining specialists & 3 & 17 & 26 & 25 & 29 \\
\hline
\end{tabular}

Source: self-analysis. 
In the research described, the respondents were also asked to conduct an assessment of the operational aims facing personnel controlling (compare Table 6). The evaluation was conducted according to the criteria accepted for the assessment of the afore-mentioned strategic aims.

Table 6. Operational aims of personnel controlling in evaluation of research entities (\%)

\begin{tabular}{|c|c|c|c|c|c|c|c|}
\hline No. & Type of aim & $\begin{array}{c}\text { Entity of human resource } \\
\text { management }\end{array}$ & 1 & 2 & 3 & 4 & 5 \\
\hline \multirow[t]{5}{*}{1} & \multirow{5}{*}{$\begin{array}{l}\text { Evaluation of way } \\
\text { of planning employment }\end{array}$} & Director & 0 & 0 & 0 & 40 & 60 \\
\hline & & Manager & 12 & 6 & 18 & 35 & 29 \\
\hline & & HR & 0 & 2 & 27 & 20 & 51 \\
\hline & & Specialist of controlling & 0 & 0 & 37 & 25 & 38 \\
\hline & & Remaining specialists & 6 & 7 & 28 & 27 & 32 \\
\hline \multirow[t]{5}{*}{2} & \multirow{5}{*}{$\begin{array}{l}\text { Evaluation of way } \\
\text { of selecting employees }\end{array}$} & Director & 0 & 20 & 20 & 40 & 20 \\
\hline & & Manager & 0 & 12 & 12 & 47 & 29 \\
\hline & & HR & 0 & 2 & 20 & 24 & 54 \\
\hline & & Specialist of controlling & 0 & 0 & 25 & 38 & 37 \\
\hline & & Remaining specialists & 3 & 7 & 24 & 33 & 33 \\
\hline \multirow[t]{5}{*}{3} & \multirow{5}{*}{$\begin{array}{l}\text { Evaluation of ways } \\
\text { of recruiting employees }\end{array}$} & Director & 0 & 0 & 40 & 20 & 40 \\
\hline & & Manager & 0 & 0 & 29 & 47 & 24 \\
\hline & & $\mathrm{HR}$ & 0 & 5 & 22 & 29 & 44 \\
\hline & & Specialist of controlling & 0 & 13 & 12 & 50 & 25 \\
\hline & & Remaining specialists. & 1 & 6 & 24 & 37 & 32 \\
\hline \multirow[t]{5}{*}{4} & \multirow{5}{*}{$\begin{array}{l}\text { Evaluation of way } \\
\text { of motivating employees }\end{array}$} & Director & 0 & 20 & 20 & 20 & 40 \\
\hline & & Manager & 0 & 6 & 18 & 41 & 35 \\
\hline & & $\mathrm{HR}$ & 0 & 0 & 15 & 20 & 65 \\
\hline & & Specialist of controlling & 0 & 0 & 0 & 13 & 87 \\
\hline & & Remaining specialists & 1 & 2 & 11 & 26 & 60 \\
\hline \multirow[t]{5}{*}{5} & \multirow{5}{*}{$\begin{array}{l}\text { Evaluation of way } \\
\text { of assessing employees }\end{array}$} & Director & 0 & 20 & 20 & 20 & 40 \\
\hline & & Manager & 0 & 6 & 23 & 59 & 12 \\
\hline & & $\mathrm{HR}$ & 0 & 2 & 24 & 17 & 57 \\
\hline & & Specialist of controlling & 0 & 0 & 12 & 38 & 50 \\
\hline & & Remaining specialists & 1 & 2 & 21 & 36 & 40 \\
\hline \multirow[t]{5}{*}{6} & \multirow{5}{*}{$\begin{array}{l}\text { Evaluation of level } \\
\text { of training and development } \\
\text { of employees }\end{array}$} & Director & 0 & 0 & 60 & 20 & 20 \\
\hline & & Manager & 0 & 0 & 12 & 59 & 29 \\
\hline & & $\mathrm{HR}$ & 0 & 0 & 5 & 22 & 73 \\
\hline & & Specialist of controlling & 0 & 0 & 0 & 25 & 75 \\
\hline & & Remaining specialists & 1 & 2 & 18 & 35 & 44 \\
\hline \multirow[t]{5}{*}{7} & \multirow[t]{5}{*}{ Evaluation of work efficiency } & Director & 0 & 0 & 0 & 60 & 40 \\
\hline & & Manager & 0 & 0 & 24 & 29 & 47 \\
\hline & & HR & 0 & 0 & 7 & 34 & 59 \\
\hline & & Specialist of controlling & 0 & 0 & 13 & 13 & 74 \\
\hline & & Remaining specialists & 1 & 2 & 14 & 25 & 58 \\
\hline
\end{tabular}




\begin{tabular}{|c|c|c|c|c|c|c|c|}
\hline No. & Type of aim & $\begin{array}{c}\text { Entity of human resource } \\
\text { management }\end{array}$ & 1 & 2 & 3 & 4 & 5 \\
\hline \multirow[t]{5}{*}{8} & \multirow[t]{5}{*}{ Evaluation of labour costs } & Director & 0 & 20 & 20 & 0 & 60 \\
\hline & & Manager & 0 & 12 & 6 & 29 & 53 \\
\hline & & HR & 0 & 5 & 12 & 12 & 71 \\
\hline & & Specialist of controlling & 0 & 0 & 0 & 25 & 75 \\
\hline & & Remaining specialists & 1 & 7 & 16 & 32 & 44 \\
\hline \multirow[t]{5}{*}{9} & \multirow{5}{*}{$\begin{array}{l}\text { Evaluation } \\
\text { of communication and flow } \\
\text { of information transferred } \\
\text { to employees }\end{array}$} & Director & 0 & 0 & 0 & 60 & 40 \\
\hline & & Manager & 6 & 6 & 29 & 29 & 30 \\
\hline & & HR & 0 & 5 & 20 & 21 & 54 \\
\hline & & Specialist of controlling & 0 & 0 & 0 & 50 & 50 \\
\hline & & Remaining specialists & 2 & 14 & 19 & 26 & 39 \\
\hline \multirow[t]{5}{*}{10} & \multirow{5}{*}{$\begin{array}{l}\text { Evaluation of way } \\
\text { of resolving conflicts }\end{array}$} & Director & 0 & 0 & 40 & 0 & 60 \\
\hline & & Manager & 11 & 12 & 29 & 24 & 24 \\
\hline & & HR & 0 & 15 & 21 & 15 & 49 \\
\hline & & Specialist of controlling & 0 & 12 & 0 & 50 & 38 \\
\hline & & Remaining specialists & 6 & 14 & 20 & 28 & 32 \\
\hline
\end{tabular}

Source: self-analysis.

The operational aims of personnel controlling were also highly rated by the top management, specialists of controlling, but also by HR specialists who encounter the execution of the short-term aims of personnel controlling on a daily basis. It has the least significance for the specialists in the remaining departments.

\section{Conclusions}

Personnel controlling, whose main role is that of a source of advice for the board, while also participation in the creation of plans, reporting on the subject of the state of human resources, information feedback (particularly cost-wise) associated with $\mathrm{HRM}^{34}$, constitutes a significant element of management in the area of human resources ${ }^{35}$. There is a significant identification among HR specialists and the specialists of controlling with the role of operational personnel controlling that serves the analysis of labour costs, labour efficiency, as well as costs associated with the professional development of those employed.

In the context of the function of management, the role of controlling comes down to the following activities ${ }^{36}$ :

34 M. Nowak, Controlling personalny w przedsiębiorstwie, Oficyna Wolters Kluwer business, Kraków 2008.

35 E. Nowak (ed.), Controlling dla menedżerów, Wydawnictwo CeDeWu, Warszawa 2013, p. 26.

36 E. Nowak, Controlling jako podsystem zarzq̨dzania przedsiębiorstwem, [in:] E. Nowak (ed.), Controlling dla menedżerów, Wydawnictwo CeDeWu, Warszawa 2013, p. 12. 
- planning - one of the fundamental tasks of controlling is that of budgeting, which is the planning of the activities of an enterprise in terms of the notion of value;

- organizational - controlling facilitates the appropriate reorganization of the processes and activities executed in the enterprise on the basis of the gauging of their execution;

- motivational - controlling facilitates the construction of a motivational system based on the gauging of the results of the activities of units within the organization;

- controlling - controlling facilitates the ongoing monitoring of the activities of the enterprise by means of providing a system of short-term and long-term gauges, while also a gauge of the execution of the strategic aims.

In the research conducted, it is possible to note that the managerial staff mainly perceives the role of controlling in the process of taking decisions relating to the reduction of labour costs, the efficiency of the activities of the enterprise, as well as the enhancement of the processes of planning.

In summary, as indicated by the results of the research conducted, the greater the degree of awareness of utilizing controlling is represented by the entities of HRM, the higher it is rated.

\section{References}

Borkowska S., Rola zaangażowania pracowników, "Zarządzanie Zasobami Ludzkimi” 2014, no. 2, pp. 9-26.

Břečková P., Havlíček K., Leaders Management and Personnel Controlling in SMEs, "European Research Studies" 2013, vol. XVI, issue 4, pp. 3-14.

Co to jest controlling, https://www.icv-controlling.com/pl/o-controllingu/co-to-jest-controlling. html (accessed: 1.12.2019).

Deyhle A., Personal-Controlling, "Controller Magazin” 1990, no. 2, pp. 51-57, https://www.haufe .de/download/controller-magazin-ausgabe-021990-controller-magazin-139022.pdf (accessed: 22.12.2019).

Goliszewski J., Controlling - koncepcje, zastosowania, wdrożenie, Oficyna Wolters Kluwer business, Warszawa 2015.

Horvath P., Controlling, Verlag Franz Vahlen, München 2006.

Konsek-Ciechońska J., Operational and strategic controlling tools in microenterprises - case study, "Management Systems in Production Engineering" 2017, vol. 25, issue 4, pp. 278-282, http:// doi.org/10.1515/mspe-2017-0041

Król H., Istota rozwoju kapitału ludzkiego w organizacji, [in:] H. Król, A. Ludwiczyński (eds), Zarządzanie zasobami ludzkimi. Tworzenie kapitału ludzkiego organizacji, Wydawnictwo Naukowe PWN, Warszawa 2006, pp. 423-451.

Kuźniarska A., Controlling personalny w sieciach handlu detalicznego, Wydawnictwo Uniwersytetu Jagiellońskiego, Kraków 2019. 
Marciniak S., Controlling. Filozofia, projektowanie, Difin, Warszawa 2001.

Nowak E., Controlling jako podsystem zarzq̨dzania przedsiębiorstwem, [w:] E. Nowak (ed.), Controlling dla menedżerów, Wydawnictwo CeDeWu, Warszawa 2013, pp. 9-31.

Nowak M., Controlling personalny w przedsiębiorstwie, Oficyna Wolters Kluwer business, Kraków 2008.

Nowak E. (ed.), Controlling dla menedżerów, Wydawnictwo CeDeWu, Warszawa 2013.

Oleksyn T., Zarządzanie zasobami ludzkimi w organizacji, Wolters Kluwer, Warszawa 2017.

Pocztowski A., Zarządzanie zasobami ludzkimi, Polskie Wydawnictwo Ekonomiczne, Warszawa 2018.

Pocztowski A., Zarzq̨dzanie zasobami ludzkimi. Zarys problematyki i metod, Antykwa, Kraków 1998.

Pocztowski A., Purgal-Popiela J., Controlling personalny, [in:] M. Sierpińska (ed.), Controlling funkcyjny w przedsiębiorstwie, Oficyna Ekonomiczna, Kraków 2004, pp. 179-206.

Reichmann T., Controlling mit Kennzahlen, Verlag Franz Vahlen, München 2006.

Schulte C., Personal-Controlling mit Kennzahlen, Verlag Franz Vahlen, München 2011.

Sekuta Z., Controlling personalny. Część 1. Istota i przedmiot controllingu personalnego, Oficyna Wydawnicza Ośrodka Postępu Organizacyjnego Sp. z o.o., Bydgoszcz 1999.

Sierpińska M., Niedbała B., Controlling operacyjny w przedsiębiorstwie, Wydawnictwo Naukowe PWN, Warszawa 2008.

Sikorski A., Controlling personalny, "Zarządzanie Zasobami Ludzkimi” 2001, no. 2, pp. 49-58.

Skowronek-Mielczarek A., Leszczyński Z., Controlling, analiza i monitoring w zarządzaniu przedsiębiorstwem, Difin, Warszawa 2007.

Szejniuk A., Managerial ethics in human resource management, "Journal of Modern Science" 2016, vol. 1, no. 28, pp. 89-104.

Urlich D., Liderzy zarządzania zasobami ludzkimi, Oficyna Ekonomiczna, Kraków 2001.

Urlich D., Brockbank W., Tworzenie wartości przez HR, Wolters Kluwer business, Kraków 2008.

Vollmuth H., Controlling. Planowanie, kontrola, kierowanie, Placet, Warszawa 2007.

Walica H., Inwestycje i controlling w przedsiębiorstwie, serie "Prace Naukowe Wyższej Szkoły Biznesu w Dąbrowie Górniczej”, Wyższa Szkoła Biznesu, Dąbrowa Górnicza 2007.

\section{Abstract}

At present personnel controlling is becoming increasingly applied as a tool in the management of various areas in an organization. The herein paper presents the essence of personnel controlling applied in the field of HR, its division in terms of the nature of tasks and levels of management for operational and strategic controlling. The role played by the entities of human resource management in terms of the functioning of personnel controlling is worthy of attention. The authors at hand present their research results in this sphere. The research sample encompassed employees in managerial and non-managerial positions in terms of executing their tasks in retail trade chains. Survey research was conducted as a method of research.

Keywords: entities of human resource management, operational personnel controlling, strategic personnel controlling 